\title{
TREATMENT OF WASTEWATER WITH CONSTRUCTED WETLANDS SYSTEMS AND PLANTS USED IN THIS TECHNOLOGY - A REVIEW
}

\author{
SANJRANi, M. A. - Zhou, B. - ZhAO, H. - ZhENG, Y. P. - WANG, Y. - XiA, S. B. ${ }^{*}$ \\ School of Resources and Environmental Engineering, Wuhan University of Technology, Wuhan, \\ P. R. China \\ (e-mails:manzoor.geo@gmail.com, boxunzhou@foxmail.com,zhaoheng0802@126.com, \\ zhengyouping0614@163.com,wang569874@126.com) \\ *Corresponding author \\ e-mail:xiashibin@126.com
}

(Received 24 $4^{\text {th }}$ Jun 2019; accepted $25^{\text {th }}$ Oct 2019)

\begin{abstract}
Water issues are still here, urbanization and industries generate different types of wastes which then affect water. Many technologies have been introduced for water treatment and efforts are being made to improve and maintain water quality, while also providing easily available and low-cost technologies. Several methods which are easily available but due to high cost, they cannot be introduced everywhere, especially rural areas. Recently, constructed wetlands have been proven to be an efficient technology to treat water. With its biological, physical and chemical treatment, constructed wetland technology becomes the best choice by many countries around the world. Existing research shows that COD (Chemical Oxygen Demand), BOD5 (Biological Oxygen Demand), TKN (Total Kjeldahl Nitrogen), TSS (Total suspended solids) etc. have been removed to a significant degree by using constructed wetlands. This technology is a system of different materials, such as gravel, vegetation and recently introduced tool knows as biochar. The combination of these makes the system efficient for water treatment but some factors such as area, weather conditions, type of wastes do matter. Selection of constructed wetland type and suitable plants is very important. In this paper, efficiency of constructed wetland system, its mechanism, the types of plants used in the system and role of plants to enhance the efficiency of the wetland system from all over the world are widely reviewed and discussed.
\end{abstract}

Keywords: constructed wetlands, water treatment, removal mechanisms, removal of pollutants, plants in wetlands

\section{Introduction}

Recent environmental issues and the discovery of their solutions have been increasing rapidly throughout the world. The discharge of wastewater from industries is a threat to nature creating water borne diseases. Recently, the lack of proper wastewater treatment, rapid urbanization is making the situation worse (Varga et al., 2017; Sanjrani et al., 2017; Brix et al., 2013). There are many options available for water treatment, but wetland technology is more efficient and less-cost. One of the valuable services given by natural, restored, or constructed wetlands is that they generally protect downstream waterways from the impact of nutrient pollution. This happens naturally because constructed wetlands are complex systems with a large number of active physical, chemical, and biological processes that mutually influence each other. Nutrient removal use some of the main physical processes such as particle settling known as sedimentation or volatilization, it releases as a gas into the atmosphere, and sorption which includes a nutrient adhering to a solid or diffusing into another liquid or solid. The chemical processes are involved with transformations and precipitation. The biological processes by plants, algae, and bacteria and further process of transformation are conducted by microbes. Wetland compartments have all of these processes with water; biota i.e. plants, algae, and bacteria; litter; and soil. 
Around the world, wastewater treatment by constructed wetlands has become one of the efficient solutions (Varga et al., 2017; Sanjrani et al., 2019; Jácome, 2016).

CWs are applied to the treatment of varieties of wastewaters created either from industries or human settlements. Some of them are: food industry effluents (including dairy, abattoir, fruit, vegetables and meat industries), effluents of petrochemical and refinery industry, distillery and winery effluents, textile, aquaculture, tannery, steel and mixed industrial effluents, pulp and paper industry etc (Varga et al., 2017). CWs are planned engineered systems that are generally constructed and designed by natural processes such as wetland vegetation, soils, and their associated microbial assemblages (Vymazal, 2014). In this process, it also needs to create a specific environment for the growth of microorganisms and hydrophytes (aquatic and semi aquatic plants) which can live in aerobic, anaerobic and facultative anaerobic environmental systems. Their interactions bring many changes, such as the intensification of oxidation and reduction responsible for the removal and retention of pollutants. These processes are generally supported by sorption, sedimentation and assimilation (Skrzypiec and Gajewska, 2017).

Wastewater is being treated by different types of wetland, i.e. H.F and V.F and a combination of VF and HF systems, known as hybrid wetlands. They are also known as: horizontal subsurface flow constructed wetlands (HSSFCWs), vertical subsurface flow constructed wetlands (VSSFCWs) and free water surface constructed wetlands (FWSCW). Wetlands for the treatment of wastewater, sludge, storm-water, and leachate have been evaluated in laboratory, pilot, and full-scale studies. Due to the benefits acquired from wetlands, wetlands are now at the centres of human evolution and the development of this planet's diverse cultures. Without water we would not exist. In Europe countries, these constructed wetlands are treating water at several places, i.e. tourist resorts, farms and landfills. Various CWs systems show different results in treatment efficiency (Mander et al., 2000). Moreover, recent studies have shown that every country relies on some type of wetlands (Jiang et al., 2016; RAMSAR, 2016; Sirianuntapiboon and Jitvimolnimit, 2007).

Recently, the use of biochar to enhance constructed wetland performance in wastewater has highly appreciated. Different types of biochar have been used to promote wetlands activities. Combining both of these technologies can greatly augment the efficiency of the system. Pollutant removal performance was compared between the controlled and experimental wetland beds. Study reveals that the wetlands with biochar are more efficient as compared to the wetland with gravels alone, which had the average removal rate (Prabuddha et al., 2015). The present paper documents an overall review on the efficiency of wetland systems and common pollutant removal around the world. It also attempts about overall review on the role of the wetland plants in constructed wetlands, efficiency of constructed wetland system, its mechanism, and the types of plants used in the system. Recommendations for future studies have been recommended to improve the efficiency for better treatment.

\section{The efficiency of wetland systems for wastewater treatment}

The efficiency of wetland systems for Wastewater Treatment has been proved that it is the best technology around the world. The first experiment on the use of wetland plants for treatment of wastewater was carried in the early 1950s by Dr. Kathe Seidel in Germany. The first full scale systems were put in operation during the late 1960s and since then constructed wetland systems have been speeding throughout the world (Vymazal and Kröpfelová, 2009). Different types of wastes are being treated by wetland technology and 
have shown promising results for the removal of pollutants (Newman et al., 2015). This is the reason; this technology is developing everywhere around the world. There are now more than 1,000 constructed wetland systems (CWs) in the UK (WRC UK, 2012). In Northeastern USA and Eastern Canada, 25 full-scale CWs treated agricultural wastewater and showed an average of good removal efficiencies: BOD5, TKN, TSS, NH4+-N, NO3-$\mathrm{N}$ and TP (Rozema and Andrew, 2016a; Rozema and Zheng, 2016b). In Russia, geographical conditions and the weather, depending on the possibilities for accommodation of certain types of CWs really need careful consideration. Recently, the use of constructed wetlands for xenobiotics removal in climatic conditions in Russia has been conducted. This project was both efficient and low-cost (Schegolkova et al., 2015).

In Korea, because of its lower construction cost and simplicity in operation and maintenance, many different types of wetland treatment systems have been built during the last 10 years, the efficiency of removal of pollutants is great. However, Kim et al. (2006) identified some issues; systems suffer from the reduced effectiveness in performance during the winter. And need to evaluate the partial treatment accomplished during six to seven months per year (Kim et al., 2006). In Pakistan, this technology was introduced relatively late, between 2009 and 2010, a small NGO Sindhica Reforms Society (Sindhica) initiated "Pakistan's first community managed Constructed Wetland" with the support of Indus for All Programme-WWF Pakistan and the technical support of UN HABITAT water for Asian cities Programme, South Asia region. Constructed wetland Majeed Keerio was designed, with the realization that substrate of the wetland can rapidly fill up with debris, grit, and solids from raw waste water if these materials are not removed prior to the wetland. Therefore, Majeed Keerio was designed as: (1) Preliminary treatment: Removal of large contaminants, such as solid waste and grit to avoid operation and maintenance problems; (2) Primary treatment: Removal of suspended solids and organic matter; (3) Secondary treatment: Removal of biodegradable organic matter; (4) Tertiary treatment: Removal of specific pollutants such as nutrients. This wetland has brought good results in removing pollutants from water (Keryo, 2012).

In Egypt, there are two major challenges that affect the ecosystem and the urban environment: the first being water scarcity and the second being wastewater management. Egypt is an arid country; it is important that reusing wastewater be encouraged as it is documented that reused wastewater is safe and economically feasible. There are several available methods for wastewater treatment; however treatment by wetlands is the most effective method (ElZein et al., 2016). In Malaysia, Faculty of Engineering, Universiti Putra Malaysia has been trying to resolve water treatment issues in Malaysia. In their study (Katayon et al., 2008), results showed that the constructed wetlands have removed 27-96\% of $\mathrm{NH} 4+, 50-88 \%$ of TSS, $56-77 \%$ of COD, $20-88 \%$ of TP, and $99 \%$ of total coliform numbers. In Kerala, India, a CW system made using a laboratory scale model; including plant 'Reed' has given good results for removal efficiencies for domestic wastewater treatment at a considerable level (Midhun et al., 2016).

In Ireland, 52 constructed wetland sites from 17 local authorities were aimed to identify the best performing types of constructed wetlands; some constructed wetland sites achieved long or frequent periods of zero effluent discharge and thus did not transfer any waterborne pollution to their receptors during these periods (Hickey et al., 2017).

Besides, there are very few disadvantages of this technology. Depending on design, constructed wetlands may possess a larger land-area than other technology. Mosquito populations increased because of wetlands and can be the reason for the diseases like malaria or other diseases caused by mosquitoes. Wetlands produce about one quarter of the 
Earth's atmospheric methane through the anaerobic decomposition of organic matter. Sometimes nutrients are changed to harmless forms year-round by wetland bacteria. Constructed wetlands may not to treat highly toxic modern wastewater till it is pre-treated in special installations. In climates with cold winters, bacteria and plants living in the constructed wetland's soil die back and release their own nutrients back into the system. A constructed wetland's biological processes are not well understood. Residual pollutants may have a negative effect on the reserve's wildlife (Gutiérrez, 2011; Kielmas, 2018; Permaculture, 2015; Akers, 2012; Patil, 2016).

\section{Removal of pollutants by wetlands}

Various studies have documented that wetlands are the best and low-cost available option for removing several pollutants from water. It can be concluded that the use of constructed wetland is very effective in removing major nutrients and pollutants. Some recent studies from all over the world have been mentioned in Table 1, which prove that this technology is best option for pollutants removal up to $99 \%$.

Table 1. Removal percentage of pollutants by wetlands

\begin{tabular}{|c|c|c|c|c|c|c|c|c|}
\hline S.No. & COD & BOD $_{5}$ & TN & TKN & TSS & TDS & TP & References \\
\hline 1 & $99 \%$ & & & $94 \%$ & $98 \%$ & & $83 \%$ & $\begin{array}{l}\text { Rozema and Andrew (2016a); } \\
\text { Rozema and Zheng (2016b) }\end{array}$ \\
\hline 2 & 86.6 & $83.7 \%$ & & $36.66 \%$ & & $87.36 \%$ & & Midhun et al. (2016) \\
\hline 3 & & & $69.96 \%$ & & & & $82.4 \%$ & Patil and Munavalli (2016) \\
\hline 4 & & & & & $83 \%$ & $58 \%$ & & Haukos et al. (2016) \\
\hline 5 & $97.2 \%$ & & $90.6 \%$ & & & & & Wu et al. (2016) \\
\hline 6 & $75 \%$ & & $75 \%$ & & & & $55 \%$ & Sartori et al. (2016) \\
\hline 7 & & & $67 \%$ & & & & & Khajah, and Babatunde (2016) \\
\hline 8 & $74.6-76.6 \%$ & & $60.1-84.7 \%$ & & & & $49.3-70.7 \%$ & Chyan et al. (2016c) \\
\hline 9 & & $87.81 \%$ & & & $86.10 \%$ & $67.27 \%$ & & Upadhyay et al. (2016) \\
\hline 10 & $89.2 \%$ & & $90.0 \%$ & & & & $50.3 \%$ & Maucieri et al. (2016) \\
\hline 11 & $91 \%$ & & & & & & & Sultana et al. (2016) \\
\hline 12 & & & $60 \% \pm 12 \%$ & & & & $77 \% \pm 4 \%$ & Mateus et al. (2016) \\
\hline 13 & $95.6 \%$ & & $85.8 \%$ & & & & & Fan et al. (2016) \\
\hline 14 & $91.3 \%$ & & $58.3 \%$ & & & & $79.5 \%$ & Prabuddha et al. (2015) \\
\hline 15 & & & & & $85 \%$ & & $68 \%$ & Niu et al. (2016) \\
\hline 16 & $83-88 \%$ & $90-95 \%$ & & & $89-93 \%$ & & & Carballeira et al. (2016) \\
\hline 17 & $66 \%$ & & $79 \%$ & & & & & Uggetti et al. (2016) \\
\hline 18 & $91 \pm 7 \%$ & $95 \pm 5 \%$ & $70 \pm 10 \%$ & & & & $90 \pm 6 \%$ & Yin et al. (2016) \\
\hline 19 & & $81 \%$ & & $75 \%$ & $83 \%$ & & $64 \%$ & $\begin{array}{l}\text { Rozema and Andrew (2016a); } \\
\text { Rozema and Zheng (2016b) }\end{array}$ \\
\hline 20 & $69 \%$ & & $69 \%$ & & & & & Wu et al. (2016) \\
\hline 21 & & & $43 \%$ & $38 \%$ & & & & $\begin{array}{l}\text { Vymazal and Kröpfelová } \\
\qquad(2009)\end{array}$ \\
\hline 22 & $65 \%$ & & $43 \%$ & & & & & Wang et al. (2016a) \\
\hline 23 & $68.1 \%$ & & & $78.25 \%$ & $86.5 \%$ & & $64.85 \%$ & Zhao et al. (2016) \\
\hline 24 & & & $71 \%$ & & & & & He et al. (2016) \\
\hline
\end{tabular}

The data shows that high levels of removal were detected for Total Phosphorus (TP) and Soluble Reactive Phosphorus (SRP), Total Nitrogen, ammonium/ammonia, nitrate and nitrite, Biological Oxygen Demand (BOD), Chemical Oxygen Demand 
(COD), and Suspended Sediments (SS). Large amounts were reduced for all these parameters. It can be concluded that constructed wetland systems are effective for the reduction of several pollutants

\section{Removal mechanisms and wastewater constituents}

There are many mechanisms involved in the wetlands system which can remove BOD, COD, and Nitrogen, as shown in Table 2.

Table 2. Removal mechanisms and wastewater constituents. (Source: modified from: Newman et al., 2015; Keryo, 2012; FCN, 2014)

\begin{tabular}{c|c}
\hline \multicolumn{2}{c}{ Removal mechanisms and wastewater constituents } \\
\hline Wastewater constituents & Removal mechanisms \\
\hline Heavy metals & Sedimentation, adsorption, plant uptake, chemical precipitation, infiltration \\
\hline Bacteria/pathogens & Sedimentation, natural die off \\
\hline Synthetic organics & Sedimentation, adsorption, oxidation, volatilization, infiltration \\
\hline Hydrocarbons & Bio-filtration, microbial decomposition, oxidation, plant uptake metabolism \\
\hline Total phosphorus & Matrix sorption, plant uptake, sedimentation bio-filtration \\
\hline Nitrate & Denitrification \\
\hline Nitrite & Denitrification \\
\hline Ammonia & Nitrification \\
\hline Biological oxygen demand & Sedimentation, bio-filtration, \\
\hline Chemical oxygen demand & Sedimentation, bio-filtration, oxidation \\
\hline Suspended solids & Serobic microbial degradation, anaerobic microbial degradation \\
\hline Soluble organics & uptake, matrix adsorption, ammonia volatilization \\
\hline Total nitrogen & Ammonification followed by microbial nitrification, denitrification, plant \\
\hline
\end{tabular}

\section{Efficiency of vegetation in wetlands for water treatment}

Efficiency of wetland systems increases with different vegetation for common pollutant removal; it has been demonstrated in several studies around the world. Roy et al. (2016) described that the basin morphometry of constructed wetlands is not same as natural wetlands, which explains the difference in vegetation composition. Plants provide a substrate for microorganisms, and microorganisms, with a source of carbon, are the most important processors of wastewater contaminants. There are various processes through with plants can incorporate pollutants are: (i) Phyto-extraction: the process in which a plant's leaves and roots play a role in concentrating heavy metals. (ii) Rhizo-filtration: the process in which plants roots play role in absorption and precipitations of metals from contaminated liquid. They are also used to degrade organic compounds. (iii) Phyto-stabililzation: the process in which metal-tolerant plants reduce the power of mobility of metals -- especially chlorinated compounds -- to air or groundwater. (iv) Phyto-stimulation: the process in which roots help bacterial and fungal development for biodegrading the compounds, i.e. petrochemical hydrocarbons, benzene, polyaromatic etc. (v) Phytovolatilization: the process in which plants take up heavy metals and some organic compounds via transpiration and place them into the atmosphere. (vi) Phyto-decomposition: the process in which both terrestrial and aquatic 
plants get organic compounds to decompose and decrease toxicity at a considerable level (FCN, 2014; Leiva, 2018).

Sieben et al., (2016a) studied about the classification of the vegetation in specific type of wetland habitats in semi-arid regions of South Africa and presented the overview. There are two types of resilience (physical human disturbance and altered hydrology). From this, conclusion has been drawn that hydric species are not resilient to hydrological impacts than terrestrial species. Pretorius and Brown (2016) studied different types of wetlands while planting the main drivers of vegetation species in South Africa. This study suggested that vegetation composition vary with the wetland type so they should be evaluated individually for better results. In addition, the immoderate use of these wetlands may accelerate their deterioration because tall indigenous vegetation in wetlands can be used as fibers for traditional crafts and construction (Sieben et al., 2016b; Sieben and Nyambeni, 2016c). Vegetation in CWs also plays a vital role in the removal of nutrients from wastewater because the removal efficiency depends on the type of plants. As Leung et al. (2016) studied about efficiency of CWs on treating mangrove plants (Bruguiera gymnorrhiza and Aegiceras corniculatum) and non-mangrove plants (Canna indica, Phragmites australis, and Acorus calamus). Comparisons results showed that Mangrove CWs planted with A. corniculatum gave higher application values than the non-mangrove CWs to treat toxic wastewater. Additionally, water hyacinth plant has also efficiency to remove nutrients from wastewater (Patil and Munavalli, 2016). In Eastern Africa, Moges et al. (2016) developed a plant-based index of biological integrity with 122 plant species belonging to 37 families, aiming to evaluate the long term natural wetland conditions, also provide an effective tool, and therefore, facilitate the management of wetlands. In the United States, CWs got big problem due to erosion, which is degrading playa-wetlands in this semi-arid country, so Haukos et al. (2016) evaluated the role of vegetation surrounding playa-wetlands for removal of nutrients, metal, and dissolved/suspended solids from runoff. According to the results, vegetative Buffers removed about $78 \%$ of N, $70 \% \mathrm{P}, 58 \%$ TDS and $83 \%$ TSS. It was suggested that vegetation buffers could be an economical conservation tool for playawetlands (Haukos et al., 2016). Ge et al., (2016) highlighted the influence on contaminants removal in the sense of seasonal change. In the study, efficiency of three plants was recorded. Thalia dealbata outperformed $C$. indica and Lythrum salicaria in the removal of total nitrogen $(69.96 \%)$ and total phosphorus $(82.4 \%)$ from urban storm-water runoff sewage. It is concluded that it is important to select most suitable plant communities for CWs. Wetland vegetations are important components of wetlands which play several roles in relation to the wastewater treatment processes.

\section{Plants used in constructed wetlands around the world:}

There are many plants planted in constructed wetlands (Wu, 2010; Polomski, 2007; Vymazal, 2007). Study (Oluseyi et al., 2011; Wang et al., 2016c) shows the result that three aquatic tropical plants (Canna indica, Phragmites australis and Sacciolepis africana) can be planted effectively. Some aquatic plants used in constructed wetlands are: Lemna valdiviana, Spirodela sp., Typha angustifolia, Typha domingensis, Typha latifolia, Cyperus involucratus, Cyperus giganteus, Thalia dealbata, Cyperus giganteus, Juncus effuses, Phragmites communis, Sagitaria lancifolia (Appenroth et al., 2010; Sohsalam and Sirianuntapiboon, 2008; Vymazal, 2011). 
Many studies have concluded that most commonly used species, which are given in Table 3, are robust species of emergent plants, such as the cattail (Typha latifolia), common reed (Phragmites australis), and bulrush (Appenroth et al., 2010; Sohsalam et al., 2008; Vymazal and Kröpfelová, 2011).

Table 3. Plants used in wetlands in different countries

\begin{tabular}{|c|c|c|}
\hline Location & Types of plants & References \\
\hline $\begin{array}{l}\text { Australia, Logan, } \\
\text { Queensland }\end{array}$ & $\begin{array}{c}\text { A combination of banksia intergrifolia, callistemon } \\
\text { pachyphyllus, carpobrotusglaucescens, } \\
\text { pennisetumalopecuroides }\end{array}$ & Sievers et al. (2018) \\
\hline $\begin{array}{l}\text { Australia, Logan, } \\
\text { Queensland }\end{array}$ & Melaleuca quinquenervia, Melaleuca alternifolia & $\begin{array}{c}\text { Langergraber and } \\
\text { Weissenbacher (2017) }\end{array}$ \\
\hline Australia, Melbourne & Phragmites australis & Dotro et al. (2017) \\
\hline Brazil & Heliconia psittacorum & Hu et al. (2016) \\
\hline Brazil & $\begin{array}{c}\text { Alpinia purpurata, Arundina bambusifolia, Canna } \\
\text { sp. Heliconia psittacorum L.F. }\end{array}$ & Wang et al. (2016a) \\
\hline Brazil & Hedychium coronarium, Heliconia rostrata & Gao et al. (2014) \\
\hline Brazil & Hemerocallis flava & Prata et al. (2013) \\
\hline Brazil & Heliconia psittacorum L.F. & Teodoro et al. (2014) \\
\hline China & Canna indica & Shi et al. (2004) \\
\hline China & Canna indica mixed with other species & Li et al. (2007) \\
\hline China & Canna indica Linn & Yang et al. (2007) \\
\hline China & Canna indica & Zhang et al. (2007a) \\
\hline China & R. carnea, I. pseudacorus, L. salicaria & Zhang et al. (2007b) \\
\hline China & Canna sp & Sun et al. (2009) \\
\hline China & Canna indica & Cui et al. (2010) \\
\hline China & $\begin{array}{l}\text { Canna indica mixed with other natural wetland } \\
\text { plants }\end{array}$ & Zhang et al. (2010) \\
\hline China & $\begin{array}{l}\text { Canna indica mixed with other natural wetland } \\
\text { plants }\end{array}$ & Qiu et al. (2011) \\
\hline China & Canna indica and Hedychium coronarium & Wen et al. (2011) \\
\hline China & $\begin{array}{l}\text { Iris pseudacorus mixed with other natural wetland } \\
\text { plants }\end{array}$ & Wu et al. (2011) \\
\hline China & $\begin{array}{l}\text { Iris pseudacorus, mixed with other plants of } \\
\text { natural wetlands }\end{array}$ & Xie et al. (2012) \\
\hline China & Canna indica & Chang et al. (2012) \\
\hline China & Iris sibirica & Gao et al. (2014) \\
\hline China & Canna sp & Qiu et al. (2011) \\
\hline China & Iris sibirica & Gao et al. (2015) \\
\hline China & Canna indica $L$. & Hu et al. (2016) \\
\hline $\begin{array}{l}\text { China, Changping, } \\
\text { Beijing }\end{array}$ & Salix babylonica & $\begin{array}{l}\text { Gautam and Greenway } \\
\text { (2014) }\end{array}$ \\
\hline China, Guangzhou & Pennisetumsineseroxb Pennisetum purpureum & $\begin{array}{l}\text { Bolton, and Greenway } \\
\text { (1999) }\end{array}$ \\
\hline China, Guangzhou & Canna indica & Saeed and Sun (2011) \\
\hline China, Guangzhou & Canna indica and windmill grass & Wu et al. (2011) \\
\hline China, Jinan & Phragmites australis & Cui et al. (2015) \\
\hline
\end{tabular}




\begin{tabular}{|c|c|c|}
\hline China, Shanghai & Phragmites australis Thypalatifolia & Huang et al. (2016) \\
\hline China, Shanghai & Iris sibirica Thaliadealbata & Peng et al. (2014) \\
\hline China, Wuhan & Thypaorientalis Canna indica & Wu et al. (2015) \\
\hline China, Wuhan & Juncuseffusus & Xu et al. (2015) \\
\hline China, Xi'an & Phragmites australis & Li et al. (2008) \\
\hline China, Xi'an & Phragmitesaustralis, T orientalis & Zhong et al. (2015) \\
\hline China, Cuihua, Xi'an & Thypalatifolia & Chang et al. (2012) \\
\hline Chile & Zantedeschia aethiopica, Canna spp. and Iris spp & Morales et al. (2013) \\
\hline Chile & Tulbaghia violácea, and Iris pseudacorus. & Burgos et al. (2016) \\
\hline Colombia & Heliconia psittacorum & $\begin{array}{l}\text { Madera-Parra et al. } \\
\text { (2015) }\end{array}$ \\
\hline Colombia & Alpinia purpurata & $\begin{array}{c}\text { Marrugo-Negrete et al. } \\
\text { (2016) }\end{array}$ \\
\hline Colombia & Heliconia psitacorum & $\begin{array}{l}\text { Toro-Vélez et al. } \\
\qquad(2016)\end{array}$ \\
\hline Costa Rica & $\begin{array}{c}\text { Ludwigia inucta, Zantedechia aetiopica, } \\
\text { Hedychium coronarium and Canna generalis }\end{array}$ & $\begin{array}{l}\text { León and Cháves } \\
(2010)\end{array}$ \\
\hline Cuba & Cyperus alternifolius & Zheng et al. (2016) \\
\hline $\begin{array}{l}\text { Czech republic, } \\
\text { Trebon }\end{array}$ & Phragmites australis Phalarisarundinacea & Zheng et al. (2015) \\
\hline Egypt, Giza & Phragmites australis & Wang et al., (2016b) \\
\hline Egypt & Canna sp & $\begin{array}{l}\text { Abou-Elela and Hellal } \\
\text { (2012) }\end{array}$ \\
\hline Egypt & Canna sp & $\begin{array}{l}\text { Abou-Elela et al. } \\
\text { (2013) }\end{array}$ \\
\hline Egypt, Manzala lake & Phragmites australis Thypalatifolia & Perez et al. (2014) \\
\hline Estonia, Paistu & Phragmites australis & Vymazal (2011) \\
\hline Greece & Phragmites australis Thypalatifolia & $\begin{array}{l}\text { Abou-Elela et al. } \\
(2013)\end{array}$ \\
\hline Greece, Pompia & Phragmites australis Arundadonax & El-Sheikh et al. (2010) \\
\hline India, Nagpur & Thypalatifolia & Öovel et al. (2007) \\
\hline India & Canna indica & $\begin{array}{l}\text { Choudhary et al. } \\
(2010)\end{array}$ \\
\hline India & Canna indica & Yadav et al. (2012) \\
\hline India & Heliconia angusta & Saumya et al. (2015) \\
\hline India & Canna generalis & Ojoawo et al. (2015) \\
\hline India & Canna Lily & Haritash et al. (2015) \\
\hline India & Canna indica & $\begin{array}{l}\text { Patil and Munavalli } \\
(2016)\end{array}$ \\
\hline India & Polianthus tuberosa L. & $\begin{array}{l}\text { Singh and Srivastava } \\
(2016)\end{array}$ \\
\hline India, Patancheru & Thypa Eichhorniacrassipes & $\begin{array}{c}\text { Akratos and Tsihrintzis } \\
(2007)\end{array}$ \\
\hline Indonesia, Bandung & Phragmiteskarka & Tsihrintzis et al. (2007) \\
\hline Iran, Isfahan & P. australis (PA) T. latifolia (TL) A. donax (AD) & $\begin{array}{c}\text { Kadaverugu et al. } \\
(2016)\end{array}$ \\
\hline Ireland & Iris pseudacorus & $\begin{array}{l}\text { Gill and O’Luanaigh } \\
\text { (2010) }\end{array}$ \\
\hline
\end{tabular}




\begin{tabular}{|c|c|c|}
\hline Israel, Kiryat & Lemnagibba L. & Datta et al. (2016) \\
\hline Italy, Florence & Phragmites australis & Kurniadie (2011) \\
\hline Italy & Zantedeschia aethiopica, Canna indica & Macci et al. (2015) \\
\hline Japan, Mito & Zizanialatifolia & $\begin{array}{c}\text { Haghshenas } \\
\text { Adarmanabadi (2016) }\end{array}$ \\
\hline Kenya, Nairobi & Cyperus papyrus & RAN et al. (2004) \\
\hline Kenya & Canna sp & Kimani et al. (2012) \\
\hline Mexico & Zantedeschia aethiopoca & $\begin{array}{l}\text { Belmont and Metcalfe } \\
\text { (2003) }\end{array}$ \\
\hline Mexico & Zantedeschia Aethiopica and Canna flaccida & Belmont et al. (2004) \\
\hline Mexico & Heliconia psittacorum & Orozco et al. (2006) \\
\hline Mexico & $\begin{array}{c}\text { Strelitzia reginae, Zantedeschia esthiopica, Canna } \\
\text { hybrids, Anthurium andreanum, Hemerocallis } \\
\text { Dumortieri }\end{array}$ & Zurita et al. (2006) \\
\hline Mexico & Zantedeschia aethiopica & Zurita et al. (2008) \\
\hline Mexico & Zantedeschia aethiopica & $\begin{array}{l}\text { Ramírez-Carrillo } \\
(2009)\end{array}$ \\
\hline Mexico & Strelitzia reginae, Anthurium, andreanum. & Zurita et al. (2009) \\
\hline $\begin{array}{l}\text { Mexico, Ocotlan, } \\
\text { Jalisco }\end{array}$ & $\begin{array}{c}\text { Stretlitziareginae A combination of } \\
\text { Stretlitziareginae, Anthuriumandreanum and } \\
\text { Aganpanthusafricanus }\end{array}$ & $\begin{array}{l}\text { Masi and Martinuzzi } \\
\qquad(2007)\end{array}$ \\
\hline Nepal & Canna latifolia & Singh et al. (2009) \\
\hline Nigeria, Akure & Azollapinnata & Abe et al. (2014) \\
\hline Portugal & Canna indica mixed with other plants & Calheiros et al. (2007) \\
\hline Portugal & $\begin{array}{c}\text { Canna flaccida, Zantedeschia aethiopica, Canna } \\
\text { indica, Agapanthus africanus and Watsonia } \\
\text { borbonica }\end{array}$ & Calheiros et al. (2015) \\
\hline Singapore, Nanyang & Thypaaugustifolia & Mburu et al. (2012) \\
\hline Spain & Iris $s p$ & García et al. (2007) \\
\hline Spain & Iris pseudacorus & Ansola et al. (2003) \\
\hline $\begin{array}{l}\text { Spain, Santiago of } \\
\text { Compostela }\end{array}$ & Phragmites australis & Akinbile et al. (2016) \\
\hline $\begin{array}{l}\text { Spain, Galicia, } \\
\text { Boimorto }\end{array}$ & Phragmites australis & Zhang et al. (2012) \\
\hline Spain, Valencia & Cattail Phragmites australis & Ávila et al. (2016) \\
\hline Srilanka & Canna iridiflora & Weragoda et al. (2012) \\
\hline Srilanka, Peradeniya & Thypaaugustifolia & Vazquez et al. (2013) \\
\hline Taiwan & Canna indica & Chyan et al. (2016a) \\
\hline Taiwan & Canna indica & Chyan et al. (2016b) \\
\hline Thailand & Canna sp & $\begin{array}{l}\text { Sirianuntapiboo } \mathrm{n} \text { and } \\
\text { Jitvimolnimit (2007) }\end{array}$ \\
\hline Thailand & $\begin{array}{l}\text { Canna siamensis, Heliconia spp and Hymenocallis } \\
\text { littoralis }\end{array}$ & Sohsalam et al. (2008) \\
\hline Thailand & $\begin{array}{l}\text { Heliconia psittacorum L. } f . \text { and Canna generalis } \\
\text { L. Bailey }\end{array}$ & Konnerup et al. (2009) \\
\hline Thailand & Canna hybrida & $\begin{array}{c}\text { Kantawanichkul et al. } \\
(2009 \mathrm{a})\end{array}$ \\
\hline Thailand & Cannae lilies, Heliconia & Brix et al. (2011) \\
\hline
\end{tabular}




\begin{tabular}{|c|c|c|}
\hline Thailand, Bangkok & Typhaangustifolia Cyperusinvolucratus & Martin et al. (2013a) \\
\hline Thailand, Bangkok & Canna & Eerakoon et al. (2016) \\
\hline Thailand, Chiang Mai & Oryzasativa $L$ & $\begin{array}{c}\text { Mayo and Bigambo } \\
(2005)\end{array}$ \\
\hline Thailand, Petchaburi & $\begin{array}{l}\text { A combination of Thypaangustifolia, } \\
\text { Cyperuscorymbosus, Brachiariamutica, } \\
\text { Digitariabicornis, Vetiveriazizaniodes, spartina } \\
\text { patents, Leptochloafusca, Echinodoruscordifulia }\end{array}$ & $\begin{array}{l}\text { Kantawanichkul et al. } \\
\text { (2009b) }\end{array}$ \\
\hline Tunisia, Joogar & Phragmitesaustralis and thypalatifolia & $\begin{array}{c}\text { Klomjek and } \\
\text { Nitisoravut (2005) }\end{array}$ \\
\hline Turkey & Iris australis & Tunçsiper (2009) \\
\hline Turkey, Garip & Thypalatifolia & Konnerup et al. (2009) \\
\hline Uganda, Kampala & Cyperus papyrus & $\begin{array}{l}\text { Kantawanichkul and } \\
\text { Duangjaisak (2011) }\end{array}$ \\
\hline USA & Canna flaccida, Gladiolus sp., Iris sp. & Neralla et al. (2000) \\
\hline USA & Canna sp. & Zachritz et al. (2008) \\
\hline United Kingdom & Iris pseudacorus & $\begin{array}{c}\text { McKinlay and } \\
\text { Kasperek (1999) }\end{array}$ \\
\hline Vietnam, Can Tho & Phragmitesvallatoria & Kouki et al. (2009) \\
\hline
\end{tabular}

\section{Most commonly plants used in CW}

Around the world, four most commonly genera plants used in CW are: Canna, Iris, Heliconia, Zantedeschia, Phragmites and Typhas have been recommended as the main species planted in constructed wetland due to their effectiveness, even though they are considered invasive and outside their native range. Common plants planted in constructed wetlands in North America are cattails (Typha latifolia). Cattails (Typha latifolia) have the ability to grow at different water depths, are easy to transport and transplant, and they have broad tolerance of water composition (including $\mathrm{pH}$, dissolved oxygen, salinity, and contaminant concentrations), making them ideal plants for constructed wetlands. Another species known as Common Reed (Phragmites australis) is also commonly found in both black-water treatment and in grey-water treatment systems to clean wastewater. Bulrush is also known as effective species (Appenroth et al., 2010; Sohsalam and Sirianuntapiboon, 2008; Vymazal, 2011).

\section{Conclusion}

The overall finding of this review is that all wetland types are very effective at reducing major nutrients and suspended sediments. Constructed wetland is recommended for wastewater treatment because it treats water biologically, physically and chemically, making it the best option. It is no surprise that many countries around the world opt to use constructed wetlands. The data previously published have concluded that consistently high levels of removal were found for Total Nitrogen, nitrate and nitrite, ammonium/ammonia, Total Phosphorus (TP), Biological Oxygen Demand (BOD), Chemical Oxygen Demand (COD) and Suspended Sediments (SS). Therefore, it can be concluded that wetland systems are effective for the reduction of all of these parameters as they were reduced by large amounts. While reviewing, it was found that "Biochar" is being used in wetlands. The use of biochar to enhance 
constructed wetland performance in wastewater has highly appreciated. Different types of biochar have been used to promote wetlands activities. Combining both of these technologies can greatly augment the efficiency of the system, so it is recommended that Biochar from different materials be considered for further improvement. With this change, societies around the world may get easy and sustainable way of water treatment, especially in the affected areas, while also keeping in mind of the social, cultural and economic status of the population. It is concluded that most of plants play a vital role to enhance the efficiency of wetlands to treat all the types of wastewater, either it is natural wetlands or constructed wetlands. Several studies around the world have proved that plants have ability to remove the contaminant at considerable level.

It is recommended that before selection of plants for wetlands; consider the condition such as weather of the area, type of wetlands, and type of water need to be treated so that removal percentage should be higher. Addition of biochar/ACF boosts efficiency of the system. It is recommended that select an efficient material for media. Wood biochar is less expensive than other synthetic materials like granular activated carbon. Therefore, use of wood biochar for removal efficiency is recommended as a simple, cost effective, and environmentally friendly solution for constructed wetland system especially in developing countries. Furthermore, future research is needed on combination of different advanced techniques to undertake stability and mechanism of things which are involved in the constructed wetland system for better solution during water treatment. Additionally, it is important to elucidate the possibility and efficiency of suitable approaches to treat and safely dispose of the resultant material after the treatment process. There is still gap and need to investigate as industrialization and urbanization is changing the world every day and creating different water issues.

Acknowledgements. This research was supported by the Demonstration of Integrated Management of Rocky Desertification and Enhancement of Ecological Service Function in Karst Peak-cluster Depression (grant no.:2016YFC0502400).

\section{REFERENCES}

[1] Abe, K., Komada, M., Ookuma, A., Itahashi, S., Banzai, K. (2014): Purification performance of a shallow free-water-surface constructed wetland receiving secondary effluent for about 5 years. - Ecological Engineering 69: 126-133.

[2] Abou Elela, S., Hellal, M. (2012): Municipal wastewater treatment using vertical flow constructed wetlands planted with Canna, Phragmites and Cyprus. - Ecol Eng. 47: 209213.

[3] Abou Elela, S., Golinielli, G., Abou Taleb, E., Hellal, M. (2013): Municipal wastewater treatment in horizontal and vertical flows constructed wetlands. - Ecol Eng. 61: 460-468. DOI: https://doi.org/10.1016/j.ecoleng.2013.10.010.

[4] Akers, C. (2012): Constructed wetlands. - online available at: https://sites.biology.colostate.edu/phytoremediation/2012/Constructed\%20wetlands $\% 20 \mathrm{~b}$ y\%20Chris\%20Akers.pdf.

[5] Akinbile, C. O., Ogunrinde, T. A., Che Bt Man, H., Aziz, H. A. (2016): Phytoremediation of domestic wastewaters in free water surface constructed wetlands using Azollapinnata. - International Journal of Phytoremediation 18: 54-61.

[6] Akratos, C. S., Tsihrintzis, V. A. (2007): Effect of temperature, HRT, vegetation and porous media on removal efficiency of pilot-scale horizontal subsurface flow constructed wetlands. - Ecological Engineering 29: 173-191. 
[7] Ansola, G., González, J. M., Cortijo, R., de Luis, E. (2003): Experimental and full-scale pilot plant constructed wetlands for municipal wastewaters treatment. - Ecol. Eng 21(1): 43-52. DOI: https://doi.org/10.1016/j.ecoleng.2003.08.002.

[8] Appenroth, K. J., Krech, K., Keresztes, Á., Fischer, W., Koloczek, H. (2010): Effects of nickel on the chloroplasts of the duckweeds Spirodela polyrhiza and Lemna minor and their possible use in biomonitoring and phytoremediation. - Chemosphere 78: 216-223.

[9] Ávila, C., García, J., Garfí, M. (2016): Influence of hydraulic loading rate, simulated storm events and seasonality on the treatment performance of an experimental three-stage hybrid CW system. - Ecological Engineering 87: 324-332.

[10] Belmont, M. A., Metcalfe, C. D. (2003): Feasibility of using ornamental plants (Zantedeschia aethiopica) in subsurface flow treatment wetlands to remove nitrogen, chemical oxygen demand and nonylphenol ethoxylate surfactants - a laboratory-scale study. - Ecol Eng 21: 233-247. DOI: https://doi.org/10.1016/j.ecoleng.2003.10.003.

[11] Belmont, M. A., Cantellano, E., Thompson, S., Williamson, M., Sánchez, A., Metcalfe, C. D. (2004): Treatment of domestic wastewater in a pilot scale natural treatment system in central Mexico. - Ecol Eng 23: 299-311. DOI: https://doi.org/10.1016/j.ecoleng.2004.11.003.

[12] Bolton, K. G., Greenway, M. (1999): Pollutant removal capability of a constructed Melaleucawetland receiving primary settled sewage. - Water Science and Technology 39: 199-206.

[13] Brix, H., Koottatep, T., Fryd, O., Laugesen, C. H. (2011): The flower and the butterfly constructed wetland system at Koh Phi Phi - system design and lessons learned during implementation and operation. - Ecol Eng. 37(5): 729-735, DOI: https://doi.org/10.1016/j.ecoleng.2010.06.035.

[14] Brix, H., Currie, K. I., Mikaloff Fletcher, S. E. (2013): Seasonal variability of the carbon cycle in subantarctic surface water in the South West Pacific. - Global Biogeochemical Cycles 27:1: 200-211

[15] Burgos, V., Araya, F., Reyes-Contreras, C., Vera, I., Vidal, G. (2016): Performance of ornamental 423 plants in mesocosm subsurface constructed wetlands under different organic sewage loading constructed wetlands under different organic sewage loading. Ecol Eng. 99: 246-255. DOI: https://doi.org/10.1016/j.ecoleng.2016.11.058.

[16] Calheiros, C. S., Rangel, O. S. S., Castro, P. K. L. (2007): Constructed wetland systems vegetated with different plants applied to the treatment of tannery wastewater. - Water Res. 41: 1790-1798. DOI: https://doi.org/10.1016/j.watres.2007.01.012.

[17] Calheiros, C., Bessa, V., Mesquita, R., Brix, H., Rangel, A., Castro, P. (2015): Constructed wetlands with a polyculture of ornamental plants for wastewater treatment at a rural tourism facility. $\quad$ Ecol Eng. 79: 1-7. DOI: https://doi.org/10.1016/j.ecoleng.2015.03.001.

[18] Carballeira, T., Ruiz, I., Soto, M. (2016): Effect of plants and surface loading rate on the treatment efficiency of shallow subsurface constructed wetlands. - Ecol. Eng. 90: 203214.

[19] Chang, J.-J., Wu, S.-Q., Dai, Y.-R., Liang, W., Wu, Z.-B. (2012): Treatment performance of integrated vertical-flow constructed wetland plots for domestic wastewater. Ecological Engineering 44: 152-159.

[20] Choudhary, A. K., Kumar, S., Sharma, C. (2010): Removal of chlorinated resin and fatty acids from paper mill wastewater through constructed wetland. - World Acad Sci Eng Technol. 80: 67-71.

[21] Chyan, J. M., Jhu, Y. X., Chen, I., Shiu, R. (2016a): Improvement of nitrogen removal by external aeration and intermittent circulation in a subsurface flow constructed wetland of landscape garden ponds. - Proc Saf Environ Prot. 104: 587-597. DOI: https://doi.org/10.1016/j.psep.2016.02.016.

[22] Chyan, J. M., Lin, C. J., Lin, Y. C., Chou, Y. A. (2016b): Constructed wetland using corncob charcoal. - Int. Biodeterior. Biodegrad. 113: 146-154. 
[23] Chyan, J. M., Lu, C. C., Shiu, R. F., Bellotindos, L. (2016c): Purification of landscape water by using an innovative application of subsurface flow constructed wetlands. Environ Scie Pollut Res. 23: 535-545. DOI: https://doi.org/10.1007/s11356-015-5265.

[24] Cui, L., Ouyang, Y., Lou, Q., Yang, F., Chen, Y., Zhu, W., Luos, S. (2010): Removal of nutrients from wastewater with Canna indica L. under different vertical-flow constructed wetland conditions. - Ecol Eng. 36: 1083-1088. DOI: https://doi.org/10.1016/j.ecoleng.2010.04.026.

[25] Cui, L., Ouyang, Y., Yang, W., Huang, Z., Xu, Q., Yu, G. (2015): Removal of nutrients from septic tank effluent with baffle subsurface-flow constructed wetlands. - Journal of Environmental Management 153: 33-39.

[26] Datta, A., Wani, S., Patil, M., Tilak, A. (2016): Field scale evaluation of seasonal wastewater treatment efficiencies of free surface-constructed wetlands in ICRISAT, India. - Current Science 110: 1756-1763.

[27] Dotro, G., Langergraber, G., Molle, P., Nivala, J., Puigagut Juárez, J., Stein, O. R., von Sperling, M. (2017): "Treatment wetlands". Volume 7. Biological Wastewater Treatment Series. - IWA Publishing, London.

[28] Eerakoon, W. G., Jinadasa, K., Herath, G., Mowjood, M., Zhang, D., Tan, S. K., Jern, N. W. (2016): Performance of tropical vertical subsurface flow constructed wetlands at different hydraulic loading rates. - CLEAN - Soil, Air, Water 44: 938-948.

[29] El-Sheikh, M. A., Saleh, H. I., El-Quosy, D. E., Mahmoud, A. A. (2010): Improving water quality in polluted drains with free water surface constructed wetlands. Ecological Engineering 36: 1478-1484.

[30] ElZein, Z., Abdou, A., Abd ElGawad, I. (2016): Constructed wetlands as a sustainable wastewater. - Procedia Environmental Sciences. doi.org/10.1016/j.proenv.2016.04.053.

[31] Fan, J., Zhang, J., Guo, W., Liang, S., Wu, H. (2016): Enhanced long-term organics and nitrogen removal and associated microbial community in intermittently aerated subsurface flow constructed wetlands. - Bioresour. Technol. 214: 871-875.

[32] FCN (2014): Fourth Corner Nurseries. - http://fourthcornernurseries.com/.

[33] Gao, J., Wang, W., Guo, X., Zhu, S. (2014): Nutrient removal capability and growth characteristics of Iris sibrica in subsurface vertical flow constructed wetlands in winter. Ecol Eng. 70: 351-361. DOI: https://doi.org/10.1016/j.ecoleng.2014.06.006.

[34] Gao, J., Zhang, J., Ma, N., Wang, W., Ma, C., Zhang, R. (2015): Cadmium removal capability and growth characteristics of Iris sibrica in subsurface vertical flow constructed wetlands. - Ecol Eng. 84: 443-450. DOI: https://doi.org/10.1016/j.ecoleng.2015.07.024.

[35] García, M., Soto, F., González, J. M., Bécares, E. A. (2007): comparison of bacterial removal efficiencies in constructed wetlands and algae-based systems. - Ecol. Eng. 32(3): 238-243. DOI: https://doi.org/10.1016/j.ecoleng.2007.11.012.

[36] Gautam, D., Greenway, M. (2014): Nutrient accumulation in five plant species grown inbioretention systems dosed with wastewater. - Australasian Journal of Environmental Management 21: 453-462.

[37] Ge, Z., Feng, C., Wang, X., Zhang, J. (2016): Seasonal applicability of three vegetation constructed floating treatment wetlands for nutrient removal and harvesting strategy in urban stormwater retention pond. - Int. Biodeterior. \& Biodegrad. 112: 80-87.

[38] Gill, L., O'luanaigh, N. (2010): Nutrient removal from on-site wastewater in horizontal 473 subsurface flow constructed wetlands in Ireland. - Water Pract Techn. 6(3): 1-2. DOI: https://doi.org/10.1016/j.ecoleng.2010.06.002.

[39] Gutiérrez Mosquera, H., Peña-Varón, M. (2011): Eliminación de nitrógeno en un humedal construido subsuperficial, plantado con Heliconia psíttacorum. - Tecnología Ciencias del Agua 11(3): 49-60. http://www.scielo.org.mx/scielo.php?pid=S200724222011000300004\&script=sci_arttext

[40] Haghshenas Adarmanabadi, A., Heidarpour, M., Tarkesh-Esfahani, S. (2016): Evaluation of horizontal-vertical subsurface hybrid constructed wetlands for tertiarytreatment of 
conventional treatment facilities effluents in developing countries. - Water, Air, \& Soil Pollution 227: 1-18.

[41] Haritash, A. K., Sharma, A., Bahel, K. (2015): The potential of Canna lily for wastewater treatment under Indian conditions. - Int J Phytoremed. 17(10): 999-1004. DOI: https://doi.org/10.1080/15226514.2014.1003790.

[42] Haukos, D. A., Johnson, L. A., Smith, L. M., McMurry, S. T. (2016): Effectiveness of vegetation buffers surrounding playa wetlands at contaminant and sediment amelioration. - J. Environ. Manage. 181: 552-562.

[43] He, K., Lv, T., Wu, S., Guo, L., Ajmal, Z., Luo, H. (2016): Treatment of alkaline stripped effluent in aerated constructed wetlands: feasibility evaluation and performance enhancement. - Water. https://doi.org/10.3390/w8090386.

[44] Hickey, A., Arnscheidt, J., Joyce, E., O’Toole, J., Galvin, G., O’ Callaghan, M., Conroy, K., Killian, D., Shryane, T., Hughes, F., Walsh, K., Kavanagh, E., (2017): An assessment of the performance of municipal constructed wetlands in Ireland. - J Environ Manage. 15(210): 263-272. DOI: 10.1016/j.jenvman.2017.12.079.

[45] Hu, Y., He, F., Ma, L., Zhang, Y., Wu, Z. (2016): Microbial nitrogen removal pathways in integrated vertical-flow constructed wetland systems. - Bioresou Technol. 207: 339345. DOI: https://doi.org/10.1016/j.biortech.2016.01.106.

[46] Huang, Z., Zhang, X., Cui, L., Yu, G. (2016): Optimization of operating parameters of hybridvertical down-flow constructed wetland systems for domestic sewerage treatment. - Journal of Environmental Management 180: 384-389.

[47] Jácome, J. A., Molina, J., Suárez, J., Mosqueira, G., Torres, D. (2016): Performance of constructed wetland applied for domestic wastewater treatment: case study at Boimorto (Galicia, Spain). - Ecological Engineering 95: 324-329.

[48] Jiang, Y., Martinez-Guerra, E., Gnaneswar Gude, V., Magbanua, B., Truax, D. D., Martin, J. L. (2016): Constructed wetland for water treatment. - Water Environment Research 88(10): 1160-1191 DOI: 10.2175/106143016X14696400494650.

[49] Kadaverugu, R., Shingare, R. P., Raghunathan, K., Juwarkar, A. A., Thawale, P. R., Singh, S. K. (2016): The role of sand, marble chips and Typhalatifolia in domestic wastewater treatment-a column study on constructed wetlands. - Environmental Technology 2016: 1-8.

[50] Kantawanichkul, S., Duangjaisak, W. (2011): Domestic wastewater treatment by a constructed wetland system planted with rice. - Water Science and Technology 64: 23762380.

[51] Kantawanichkul, S., Karnchanawong, S., Jing, S. H. (2009a): Treatment of fermented fishproduction wastewater by constructed wetland system in Thailand. - Chiang MaiJ Sci. 36(2): 149-157. http://www.thaiscience.info/journals/Article/CMJS/10905526.pdf.

[52] Kantawanichkul, S., Kladprasert, S., Brix, H. (2009b): Treatment of high-strength wastewater in tropical vertical flow constructed wetlands planted with Typhaangustifoliaand Cyperusinvolucratus. - Ecological Engineering 35: 238-247.

[53] Katayon, S., Fiona, Z., Megat Mohd Noor, M. J., Abdul Halim, G., Ahmad, J. (2008): Treatment of mild domestic wastewater. - International Journal of Environmental Studies 65(1): 87-102: DOI: 10.1080/00207230601125192.

[54] Keryo, M. A. (2012): Project completed report on community managed constructed wetland in Majid Keryo, Sindh province, Pakistan. - http://sindhicapk.blogspot.com.

[55] Khajah, M., Babatunde, A. O. (2016): Wetlands for wastewater treatment. - J. Water Sustain. 2016: 43-52.

[56] Kielmas, M. (2018): The disadvantages of wetland nature reserves. https://sciencing.com/info-8396288-disadvantages-wetland-nature-reserves.html.

[57] Kim, Y., Hwang, G., Lee, J.-W., Park, J.-C., Kim, D.-S., Kang, M.-G., Chang, I.-S. (2006): Experiences with constructed wetland systems in Korea. - J Ocean Univ. China 5: 345. https://doi.org/10.1007/s11802-006-0027-9. 
[58] Kimani, R. W., Mwangi, B. M., Gichuki, C. M. (2012): Treatment of flower farm wastewater effluents using constructed wetlands in lake Naivasha Kenya. - Indian J Sci Technol. 5: 1870-1878.

[59] Klomjek, P., Nitisoravut, S. (2005): Constructed treatment wetland: a study of eight plantspecies under saline conditions. - Chemosphere 58: 585-593.

[60] Konnerup, D., Koottatep, T., Brix, H. (2009): Treatment of domestic wastewater in tropical subsurface flow constructed wetlands planted with Canna and Heliconia. - Ecol Eng. 35(2): 248-257. DOI: https://doi.org/10.1016/j.ecoleng.2008.04.018.

[61] Kouki, S., M'hiri, F., Saidi, N., Belaïd, S., Hassen, A. (2009): Performances of a constructed wetland treating domestic wastewaters during a macrophytes life cycle. Desalination 246: 452-467.

[62] Kurniadie, D. (2011): Wastewater treatment using vertical subsurface flow constructed wetland in Indonesia. - American Journal of Environmental Sciences 7(1): 15-19.

[63] Langergraber, G., Weissenbacher, N. (2017): Constructed wetland. - Water Science and Technology 75(10): 2309-2315. DOI: 10.2166/wst.2017.112.

[64] Leiva, A., Núñez, R., Gómez, G., López, D., Vidal, G. (2018): Performance of ornamental plants in monoculture and polyculture horizontal subsurface flow constructed wetlands for treating wastewater. - Ecol. Eng. 120: 116-125. DOI: https://doi.org/10.1016/j.ecoleng.2018.05.023.

[65] León, C., Cháves, D. (2010): Tratamiento de residual vacuno utilizando microalgas, la lenteja de agua Lemna aequinoctiales y un humedal subsuperficial en Costa Rica. - Rev Latinoam Biotecn Amb Alga 1(2): 155-177. DOI: https://doi.org/10.1016/j.scitotenv.2015.09.154.

[66] Leung, J. Y. S., Cai, Q., Tam, N. F. Y. (2016): Comparing subsurface flow constructed wetlands with mangrove plants and freshwater wetland plants for removing nutrients and toxic pollutants. - Ecol. Eng. 95: 129-137.

[67] Li, G., Wu, Z., Cheng, S., Liang, W., He, F., Fu, G., Zhong, F. (2007): Application of constructed wetlands on wastewater treatment for aquaculture ponds. - Wuhan University J Natur Sci 12: 1131-1135. DOI: https://doi.org/10.1007/s11859-007-0116-7.

[68] Li, J., Wen, Y., Zhou, Q., Xingjie, Z., Li, X., Yang, S., Lin, T. (2008): Influence of vegetation and substrate on the removal and transformation of dissolved organic matter in horizontal subsurface-flow constructed wetlands. - Bioresource Technology 99: 49904996.

[69] Macci, C., Peruzzi, E., Doni, S., Iannelli, R., Masciandaro, G. (2015): Ornamental plants for micropollutant removal in wetland systems. - Environ Sci Pollut Res. 22: 2406-2415. DOI: https://doi.org/10.1007/s11356-014-2949-x.

[70] Madera-Parra, C. A., Peña-Salamanca, E. J., Peña, M. R., Rousseau, D. P. L., Lens, P. N. (2015): Phytoremediation of landfill leachate with Colocasia esculenta, Gynerum sagittatum and Heliconia psittacorum in Constructed Wetlands. - - Int J Phytoreme. 17: 16-24. DOI: https://doi.org/10.1080/15226514.2013.828014.

[71] Mander, Ü., Kuusemets, V., Öövel, M., Ihme, R., Sevola, P., Pieterse, A. (2000): Experimentally constructed wetlands for wastewater treatment in Estonia. - Journal of Environmental Science and Health, Part A: Toxic/Hazardous Substances and Environmental Engineering 35(8): 1389-1401: DOI: 10.1080/10934520009377042.

[72] Marrugo-Negrete, J., Ortega-Ruíz, J., Navarro-Frómeta, A., Enamorado-Montes, G., Urango-Cárdenas, I., Pinedo-Hernández, J., Durango-Hernández, J., Estrada-Martínez, A. (2016): Remoción de cipermetrina presente en el baño de ganado utilizando humedales construidos. - Corpoica Cienc Tecnol Agrop. 17(2): 203-216.

[73] Martin, M., Gargallo, S., Hernández-Crespo, C., Oliver, N. (2013a): Phosphorus and nitrogen removal from tertiary treated urban wastewaters by a vertical flow constructed wetland. - Ecological Engineering 61: 34-42.

[74] Masi, F., Martinuzzi, N. (2007): Constructed wetlands for the Mediterranean countries: hybrid systems for water reuse and sustainable sanitation. - Desalination 215: 44-55. 
[75] Mateus, M. D., Vaz, M. M., Capela, I., Pinho, J. H. (2016): The potential growth of sugarcane in constructed wetlands designed for tertiary treatment of wastewater. - Water 8(3): 93. https://doi.org/10.3390/w8030093.

[76] Maucieri, C., Mietto, A., Barbera, A. C., Borin, M. (2016): Emerging and eco-friendly approaches for waste management. - Ecol. Eng. 94: 406-417.

[77] Mayo, A., Bigambo, T (2005): Nitrogen transformation in horizontal subsurface flowconstructed wetlands I: model development. - Physics and Chemistry of the Earth PartsA/B/C 30: 658-667.

[78] Mburu, N., Tebitendwa, S. M., Rousseau, D. P., Van Bruggen, J., Lens, P. N. (2012): Performance evaluation of horizontal subsurface flow-constructed wetlands for the treatment of domestic wastewater in the tropics. - Journal of Environmental Engineering 139: 358-367.

[79] McKinlay, R. G., Kasperek, K. (1999): Observations on decontamination of herbicide polluted water by marsh plant system. - Water Res. 33: 505-511. DOI: https://doi.org/10.1016/S0043-1354(98)00244-9.

[80] Midhun, G., Divya, L., George, J., Jayakumar, P., Suriyanarayanan, S. (2016): Wastewater Treatment Studies on Free Water Surface Constructed Wetland System. - In: Prashanthi, M., Sundaram, R. (eds.) Integrated Waste Management in India. Environmental Science and Engineering. Springer, Cham, pp. 97-109.

[81] Moges, A., Beyene, A., Kelbessa, E., Mereta, S. T., Ambelu, A. (2016): Development of a multimetric plant-based index of biotic integrity for assessing the ecological stated of forested, urban and agricultural natural wetlands of Jimma Highlands, Ethiopia. - Ecol. Indic. 71: 208-217.

[82] Morales, G., López, D., Vera, I., Vidal, G. (2013): Humedales construidos con plantas ornamentales para el tratamiento de materia orgánica y nutrientes contenidos en aguas $\begin{array}{llll}\text { servidas. } & - & \text { Theoria. } & \text { 33-46. }\end{array}$ http://revistas.ubiobio.cl/index.php/RT/article/view/1188.

[83] Neralla, S., Weaver, R. W., Lesikar, B. J., Persyn, R. A. (2000): Improvement of domesticwastewater quality by subsurface flow constructed wetlands. - Bioresour Technol. 75(1): 19-25. DOI: https://doi.org/10.1016/S0960-8524(00)00039-0.

[84] Newman, J. R., Duenas-Lopez, M. A., Acreman, M. C., Palmer-Felgate, E. J., Verhoeven, J. T. A., Scholz, M., Maltby, E. (2015): A systematic review. Do on-farm natural, restored, managed and constructed wetlands mitigate agricultural pollution in Great Britain and Ireland. - www.defra.gov.uk.

[85] Niu, S., Park, K., Cheng, J., Kim, Y. (2016): Percentile analysis of rainfall depth estimation on performance of constructed wetland. - Water Sci. Technol 73(6): 14831491.

[86] Ojoawo, S., Udayakuman, G., Naik, P. (2015): Phytoremediation of phosphorus and nitrogen with Canna $x$ generalis reeds in domestic wastewater through NMAMIT constructed wetlands. - Aquatic Procedia 4: 349-356. DOI: https://doi.org/10.1016/j.aqpro.2015.02.047.

[87] Oluseyi, E., Abimbola, S., Thevenot, D. (2011): Urban Waters: Resource or Risks? 11th Ed. - World Wide Workshop for Young Environmental Scientists, France.

[88] Öovel, M., Tooming, A., Mauring, T., Mander, Ü. (2007): Schoolhouse wastewater purification in a LWA-filled hybrid constructed wetland in Estonia. - Ecological Engineering 29: 17-26.

[89] Orozco, C., Cruz, A., Rodríguez, M., Pohlan, A. (2006): Humedal subsuperficial de flujo vertical como sistema de depuración terciaria en el proceso de beneficiado de café. - Hig Sanid Ambient. 6: 190-196.

[90] Patil, S. S., Dhulap, V. P., Kaushik, G. (2016): Application of constructed wetland using Eichhornia crassipes for sewage treatment. - J. Mater. Environ. Sci. 7(9): 3256-3263. 
[91] Patil, Y. M., Munavalli, G. R. (2016): Performance evaluation of and integrated on-site greywater treatment systm in a tropical region. - Ecol Eng. 95: 492-500. DOI: https://doi.org/10.1016/j.ecoleng.2016.06.078.

[92] Peng, L., Hua, Y., Cai, J., Zhao, J., Zhou, W., Zhu, D. (2014): Effects of plants and temperature on nitrogen removal and microbiology in a pilot-scale integrated verticalflow wetland treating primary domestic wastewater. - Ecological Engineering 64: 285290.

[93] Perez, M., Hernández, J., Bossens, J., Jiménez, T., Rosa, E., Tack, F. (2014): Vertical flow constructed wetlands: kinetics of nutrient and organic matter removal. - Water Science and Technology 70: 76-81.

[94] Permaculture (2015): Wastewater treatment and constructed wetlands. Part One. http://www.permaculture-and-sanity.com/pcarticles/constructed-wetland-wastewatertreatment-part1.php.

[95] Polomski, R. F., Bielenberg, D. G., Whitwell, T. (2007): Nutrient recovery by seven aquatic garden plants in a laboratory-scale subsurface-constructed Wetland. - Hortscience 42(7): 1674-1680.

[96] Prabuddha, G., Tae-woong, A., Seung-Mok, L. (2015): Use of biochar to enhance constructed wetland performance. - Environ. Eng. Res. http://dx.doi.org/10.4491/eer.2015.067.

[97] Prata, R., Matos, A., Cecon, P., Monaco, P., Pimenta, L. (2013): Sewage treatment in wetlands cultivated with yellow lilly. - Eng. Agrícola 33: 1144-1155. DOI: http://dx.doi.org/10.1590/S0100-69162013000600007 (in Portuguese).

[98] Pretorius, M. L., Brown, L. R. (2016): An investigation into the vegetation composition along the topographical gradients of various wetland types to inform wetland delineation in northern Kwazulu-Natal. - South Africa J of Botany 103: 345.

[99] Qiu, Z., Wang, M., Lai, W., He, F., Chen, Z. (2011): Plant growth and nutrient removal in constructed monoculture and mixed wetlands related to stubble attributes. Hydrobiologia 661: 251-260. DOI: https://doi.org/10.1007/s10750-010-0530-2.

[100] Ramírez-Carrillo, H. F., Luna-Pabello, V. M., Arredondo-Figueroa, J. L. (2009): Evaluación de un humedal artificial de flujo vertical intermitente, para obtener agua de buena calidad para la acuicultura. - Rev Mex Ing Quím. 8(1): 500 93-99.

[101] RAMSAR (2016): World wetlands. - https://www.ramsar.org/activity/world-wetlandsday.

[102] Ran, N., Agami, M., Oron, G. (2004): A pilot study of constructed wetlands using duckweed (Lemnagibba L.) for treatment of domestic primary effluent in Israel. - Water Research 38: 2241-2248.

[103] Roy, M. C., Foote, L., Ciborowski, J. J. H. (2016): Vegetation community composition in wetlands created following oil sand mining in Alberta, Canada. - J Environ. Manage. 172: 18-28.

[104] Rozema, E., R., Andrew, C., VanderZaag, J., Wood, D., Drizo, A., Zheng, Y., Madani, A., Gordon, R. J. (2016a): Constructed wetlands for agricultural wastewater treatment. Water 8: 173. DOI: 10.3390/w8050173.

[105] Rozema, E. R., Rozema, L. R., Zheng, Y. (2016b): Controlled environment systems research facility. - Ecol. Eng. 86: 262-268.

[106] Saeed, T., Sun, G. (2011): A comparative study on the removal of nutrients and organic matter in wetland reactors employing organic media. - Chemical Engineering Journal 171: 439-447.

[107] Sanjrani, M. A., Mek, T., Sanjrani, N. D., Leghari, S. J., Moryani, H. T. (2017): Current situation of aqueous arsenic contamination in Pakistan, focused on Sindh and Punjab province, Pakistan: a review. - J Pollut Eff Cont 5: 207. DOI: 10.4176/23754397.1000207.

[108] Sanjrani, M. A., Zhou, B., Zhao, H., Bhutto, S. A., Muneer, A. S., Xia, S. B. (2019): Arsenic contaminated groundwater in China and its treatment options. a review - Applied 
Ecology and Environmental Research 17(2): 1655-1683. DOI: http://dx.doi.org/10.15666/aeer/1702_16551683.

[109] Sartori, L., Canobbio, S., Fornaroli, R., Cabrini, R., Marazzi, F., Mezzanotte, V. (2016): COD, nutrient removal and disinfection efficiency of a combined subsurface and surface flow constructed wetland: a case study. - Int. J. Phytoremediation 18(4): 416-422.

[110] Saumya, S., Akansha, A., Rinaldo, J., Jayasri, M. A., Suthindhiran, K. (2015): Construction and evaluation of prototype subsurface flow wetland planted with Heliconia angusta for the treatment of synthetic greywater. - J Cleaner Product. 91: 235-240.

[111] Schegolkova, N. M., Rybka, K. Y., Almashin, D. S., Skripchinskij, A. K. (2015): Use of constructed wetlands for xenobiotics removal in climatic conditions of Russia. - Water: Chemistry and Ecology 7: 32-42. http://watchemec.ru/en/article/27436/.

[112] Shi, L., Wang, B. Z., Cao, X. D., Wang, J., Lei, Z. H., Wang, Z. R., Liu, Z. Y., Lu, B. N. (2004): Performance of a subsurface-flow constructed wetland in Southern China. - J Environ Sci. 16(3): 476-481. https://content.iospress.com/articles/journal-ofenvironmental-sciences/jes16-3-27.

[113] Sieben, E. J. J., Collins, N. B., Corry, F. T. J., Kotze, D. C., Job, N., Muasya, A. M., Venter, C. E., Mtshali, H. (2016a): The vegetation of grass lawn wetlands of floodplains and pans in semi-arid region of South Africa: description, classification and explanatory environmental factors. - S Afr J Bot. 104: 215-224.

[114] Sieben, E. J. J., Collins, N. B., Mtshali, H., Venter, C. E. (2016b): The vegetation of inland wetlands with salt-tolerant vegetation in South Africa: description, classification and explanatory environmental factors. - S. Afr. J Bot. 104: 199-207.

[115] Sieben, E. J. J., Nyambeni, T., Mtshali, H., Corry, F. T. J., Venter, C. E., MacKenzie, D. R., Matela, T. E., Pretorius, L., Kotze, D. C. (2016c): The herbaceous vegetation of subtropical freshwater wetlands in South Africa: classification, description and explanatory environmental factors. - S. Afr. J Bot. 104: 158-166.

[116] Sievers, M., Parris, K. M., Swearer, S. E., Hale, R. (2018): Stormwater wetlands can function as ecological traps for urban frogs. - Ecological Applications 28(4): 1106-1115. DOI: 10.1002/eap.1714.

[117] Singh, M., Srivastava, R. (2016): Horizontal subsurface flow constructed wetland for heavy metal removal from domestic wastewater. - Environ Progress Sustain Energy 35(1): 125-132. DOI: https://doi.org/10.1002/ep.12214.

[118] Singh, S., Haberl, R., Moog, O., Shrestha, R. R., Shrestha, P., Shrestha, R. (2009): Performance of an anaerobic baffled reactor and hybrid constructed wetland treating high-strength wastewater in Nepal — a model for DEWATs. - Ecol Eng. 35(5): 654-660. DOI: https://doi.org/10.1016/j.ecoleng.2008.10.019.

[119] Sirianuntapiboon, S., Jitvimolnimit, S. (2007): Effect of plantation pattern on the efficiency of subsurface flow constructed wetland (SFCW) for sewage treatment. - Afr J Agric Res. 2: 447-454. DOI: 10.5897/AJAR.

[120] Skrzypiec, K., Gajewska, M. H. (2017): the use of constructed wetlands for the treatment. - Journal of Water and Land Development 34: 233-240. DOI: 10.1515/jwld-2017-0058.

[121] Sohsalam, P., Sirianuntapiboon, S. (2008): Feasibility of using constructed wetland treatment for molasses wastewater treatment. - Bioresource Technol. 99: 5610-5616.

[122] Sohsalam, P., Englande, A., Sirianuntapiboon, S. (2008): Seafood wastewater treatment in constructed wetlands: tropical case. - Bioresour Technol. 99: 1218-1224. DOI: https://doi.org/10.1016/j.biortech.2007.02.014.

[123] Sultana, M. Y., Mourti, C., Tatoulis, T., Akratos, C. S., Tekerlekopoulou, A. G., Vayenas, D. V. (2016): Artificial or constructed wetlands: a suitable technology. - J. Chem. Technol. Biotechnol. 91(3): 726-732.

[124] Sun, L. P., Liu, Y., Jin, H. (2009): Nitrogen removal from polluted river by enhanced floating bed grown canna. $\quad$ Ecol Eng. 35(1): 135-140. DOI: https://doi.org/10.1016/j.ecoleng.2008.09.016. 
[125] Teodoro, A., Boncz, M., Júnior, A., Paulo, P. (2014): Disinfection of greywater pretreated by constructed wetlands using photo-fenton: influence of $\mathrm{pH}$ on the decay of Pseudomonas aeruginosa. - J. Environ. Chem. Eng. 2: 958-962.

[126] Toro-Vélez, A. F., Madera-Parra, C. A., Peñón-Varón, M. R., Lee, W. Y., Bezares-Cruz, J. C., Walker, W. S.,, Cárdenas-Henao, H., Quesada-Calderón, S., García-Hernández, H., Lens, P. N. I. (2016): BPA and NP removal from municipal wastewater by tropical horizontal subsurface constructed wetlands. - Sci Total Environ. 542: 442 93-101.

[127] Tsihrintzis, V., Akratos, C., Gikas, G., Karamouzis, D., Angelakis, A. (2007): Performance and cost comparison of a FWS and a VSF constructed wetland system. Environmental Technology 28: 621-628.

[128] Tunçsiper, B. (2009): Nitrogen removal in a combined vertical and horizontal subsurfaceflow constructed wetland system. - Desalination. 247(1-3): 466-475. DOI: https://doi.org/10.1016/j.desal.2009.03.003.

[129] Uggetti, E., Hughes-Riley, T., Morris, R. H., Newton, M. I., Trabi, C. L., Hawes, P., Puigagut (2016): Treatment wetland aeration without electricity? - J. Sci. Total Environ. 559: 212-7.

[130] Upadhyay, A. K., Singh, N. K., Bankoti, N. S., Rai, U. N (2016): Designing and construction of simulated constructed wetland for treatment of sewage containing metals. - Environ. Technol. 2016: 1-9.

[131] Varga, D. de la, Soto M, Arias CA, van Oirschot D, Kilian R, Pascual A, Alvarez JA. 2017. Constructed Wetlands for Industrial Wastewater Treatment and Removal of Nutrients. - In: Val del Rio, A., Campos Goméz, J.L., Mosquera Corral, A. (Eds) Technologies for the Treatment and Recovery of Nutrients from Industrial Wastewater. IGI global. pp. 202-230. (Advances in Environmental Engineering and Green Technologies). https://doi.org/10.4018/978-1-5225-1037-6.ch008

[132] Vazquez, M., De La Varga, D., Plana, R., Soto, M. (2013): Vertical flow constructed wetland treating high strength wastewater from swine slurry composting. - Ecological Engineering 50: 37-43.

[133] Vymazal, J. (2007): Constructed Wetlands for Wastewater Treatment: A Review. Proceedings of Taal2007: The 12th World Lake Conference: 965-980, Available online at: https://pdfs.semanticscholar.org/74be/95cf6073691249fa2b9f45702a4a7f3f440e.pdf

[134] Vymazal, J. (2011): Constructed wetland for wastewater treatment, five decades. Environ. Sci. Technol. 45: 61-69.

[135] Vymazal, J. (2014): Constructed wetlands for treatment of industrial wastewaters: a review. - Ecological Engineering 73: 724-751. DOI: 10.1016/j.ecoleng.2014.09.034.

[136] Vymazal, J., Kröpfelová, L. (2009): Removal of organics in constructed wetlands with horizontal sub-surface flow: a review of the field experience. - Sci Total Environ 15(13): 3911-22. DOI: 10.1016/j.scitotenv.2008.08.032.

[137] Vymazal, J., Kröpfelová, L (2011): A three-stage experimental constructed wetland for treatment of domestic sewage: first 2 years of operation. - Ecological Engineering 37: 9098.

[138] Wang, W., Ding, Y., Ullman, J., Ambrose, R., Wang, Y., Song, X., Zhao, Z. (2016a): Nitrogen removal performance in planted and unplanted horizontal subsurface flow constructed wetlands treating different influent COD/N ratios. - Environ Sci Pollut Res. 23: 9012-9018. DOI: https://doi.org/10.1007/s11356-016-6115-5.

[139] Wang, W., Ding, Y., Wang, Y., Song, X., Ambrose, R. F., Ullman, J. L., Winfrey, B. K. (2016c): Treatment of rich ammonia nitrogen wastewater with polyvinyl alcohol immobilized nitrifier biofortified constructed wetlands. - Ecol. Eng. 94: 7-11.

[140] Wang, W., Wang, X., Zhou, L., Liu, H., Ding, Z., Liang, Y. (2016b): Wastewater treatment in a constructed wetland followed by an oxidation pond in a rural area of China. - Environmental Engineering \& Management Journal 15(1): 199-205. 
[141] Wen, L., Hua, C., Ping, Z., Xiang, L. (2011): Removal of total phosphorus from septic tank effluent by the hybrid constructed wetland system. - Procedia Environ Sci 10: $2102-$ 2107. DOI: https://doi.org/10.1016/j.proenv.2011.09.328.

[142] Weragoda, S. K., Jinadasa, K. B. S. N., Zhang, D. Q., Gersberg, R. M., Tan, S. K., Ng, W. J. (2012): Tropical application of floating treatment wetlands. - Wetlands 32(5): 955961. DOI: https://doi.org/10.1007/s13157-012-0333-5.

[143] WRC UK (2012): Constructed wetland program. - http://www.wrcplc.co.uk/.

[144] Wu, H., Zhang, J., Li, P., Zhang, J., Xie, H., Zhang, B. (2010): Nutrient removal in constructed microcosm wetlands for treating polluted river water in northern China. Ecol Eng. 37: 560-568. DOI: https://doi.org/10.1016/j.ecoleng.2010.11.020.

[145] Wu, H., Fan, J., Zhang, J., Ngo, H. H., Guo, W., Hu, Z., Liang, S. (2015): Decentralized domestic wastewater treatment using intermittently aerated vertical flow constructed wetlands: impact of influent strengths. - Bioresource Technology 176: 163-168.

[146] Wu, H., Fan, J., Zhang, J., Ngo, H. H., Guo, W., Hu, Z., Lv, J. (2016): Optimization of organics and nitrogen removal in intermittently aerated vertical flow constructed wetlands: effects of aeration time and aeration rate. - Int. Biodeterior. Biodegrad. 113: 139-145.

[147] Wu, S., Austin, D., Liu, L., Dong, R (2011): Performance of integrated household constructed wetland for domestic wastewater treatment in rural areas. - Ecological Engineering 37: 948-954.

[148] Xie, X., He, F., Xu, D., Dong, J., Cheng, S., Wu, Z. (2012): Application of large scale integrated vertical-flow constructed wetland in Beijing Olympic forest park: design, operation and performance. - Water Environ J. 26: 100-107.

[149] Xu, Q., Hunag, Z., Wang, X., Cui, L. (2015): Pennisetumsinese Roxb and Pennisetumpurpureum Schum. as vertical-flow constructed wetland vegetation for removal of $\mathrm{N}$ and $\mathrm{P}$ from domestic sewage. - Ecological Engineering 83: 120-124.

[150] Yadav, A., Dash, P., Mohanty, A., Abbassi, R., Mishra, B. (2012): Performance assessment of innovative constructed wetland-microbial fuel cell for electricity production and dye removal. - Ecol Eng. 47: 126-131. DOI: https://doi.org/10.1016/j.ecoleng.2012.06.029.

[151] Yang, Q., Chen, Z., Zhao, J.,Gu, B. (2007): Contaminant removal of domestic wastewater by constructed wetlands: effects of plant species. - J Integrat Plant Biol. 49(4): 437-446. DOI: https://doi.org/10.1111/j.1744-7909.2007.00389.x.

[152] Yin, X., Zhang, J., Hu, Z., Xie, H., Guo, W., Wang, Q., Ngo, H. H. (2016): Using the Dashu Old rail bridge constructed wetland system for polluted river water purification and ecosystem rehabilitation. - Environ. Sci. Pollut. Res. 23(15): 15524-15531.

[153] Zachritz, W. H., Hanson, A. T., Sauceda, J. A., Fitzsimmons, K. M. (2008): Evaluation of submerged surface flow (SSF) constructed wetlands for recirculating tilapia production systems. - Aquacult Eng. 39: 16-23. DOI: https://doi.org/10.1016/j.aquaeng.2008.05.001.

[154] Zhang, D. Q., Tan, S. K., Gersberg, R. M., Zhu, J., Sadreddini, S., Li, Y. (2012): Nutrient removal in tropical subsurface flow constructed wetlands under batch and continuous flow conditions. - Journal of Environmental Management 96: 1-6.

[155] Zhang, S., Zhou, Q., Xu, D., He, F., Cheng, S., Liang, W., Du, C., Wu, Z. (2010): Vertical-flow constructed wetlands applied in a recirculating aquaculture system for channel catfish culture: effects on water quality and zooplankton. - Polish J Environ Stud 19: 1063-1070.

[156] Zhang, X. B., Liu, P., Yang, Y. S., Chen, W. R. (2007a): Phytoremediation of urban wastewater by model wetlands with ornamental hydrophytes. - J Environ Sci (China): 19(8): 902-909.

[157] Zhang, Z. H., Rengel, Z., Meney, K. (2007b): Nutrient removal from simulated wastewater using Canna indica and Schoenoplectus validus in mono- and mixed culture in wetland microcosms? - Water Air Soil Pollut. 183(1-4): 95-105. 
[158] Zhao, J., Zhao, Y., Xu, Z., Doherty, L., Liu, R. (2016): Highway runoff treatment by hybrid adsorptive media-baffled subsurface flow constructed wetland. - Ecol. Eng. 91: 231-239.

[159] Zheng, Y., Wang, X. C., Ge, Y., Dzakpasu, M., Zhao, Y., Xiong, J. (2015): Effects of annual harvesting on plants growth and nutrients removal in surface-flow constructed wetlands in northwestern China. - Ecological Engineering 83: 268-275.

[160] Zheng, Y., Wang, X. C., Dzakpasu, M., Ge, Y., Zhao, Y., Xiong, J. (2016): Performance of a pilot demonstration-scale hybrid constructed wetland system for on-site treatment of polluted urban river water in Northwestern China. - Environmental Science and Pollution Research 23: 447-454.

[161] Zhong, F., Wu, J., Dai, Y., Xiang, D., Cheng, S., Ji, H. (2015): Performance evaluation of wastewater treatment using horizontal subsurface flow constructed wetlands optimized by micro-aeration and substrate selection. - Water Science and Technology 71: 1317-1324.

[162] Zurita, F., De Anda, J., Belmont, M. (2006): Performance of laboratory-scale wetlands planted with tropical ornamental plants to treat domestic wastewater. - Water Qual Res J Canada 41(4): 410-417. DOI: https://doi.org/10.2166/wqrj.2006.044.

[163] Zurita, F., Belmont, M., De Anda, J., Cervantes-Martínez, J. (2008): Stress detection by laser-induced fluorescence in Zantedeschia aethiopica planted in subsurface-flow treatment wetlands. - Ecol Eng. 33: 110-118. DOI: https://doi.org/10.1016/j.ecoleng.2008.02.004.

[164] Zurita, F., De Anda, J., Belmont, M. (2009): Treatment of domestic wastewater and production of commercial flowers in vertical and horizontal subsurface-flow constructed wetlands. - Ecological Engineering. 35: 861-869. 